\title{
In vitro $\mathrm{N}$ degradability and $\mathrm{N}$ digestibility of raw, roasted or extruded canola, linseed and soybean
}

\author{
T. D. Turner*and M.A. McNiven \\ Department of Health Management, Atlantic Veterinary College, University of Prince Edward Island, \\ 550 University Avenue, Charlottetown, PE, C1A 4P3, Canada \\ e-mail:tyler.turner@agr.gc.ca
}

\begin{abstract}
The $\mathrm{N}$ degradability and $\mathrm{N}$ digestibility of raw, roasted or extruded oilseeds were studied using an in vitro enzyme method. The $\mathrm{N}$ degradability and $\mathrm{N}$ digestibility of canola, linseed and soybean were calculated based on the proportional difference in $\mathrm{N}$ remaining after incubation and the initial $\mathrm{N}$ content. Heat treatments increased the undegradable $\mathrm{N}$ fraction of linseed and soybean, whereas that of canola was decreased by extrusion. Heat treatments did not decrease the $\mathrm{N}$ digestibility of the oilseeds compared to raw samples. The high $\mathrm{N}$ digestibility and lower acid detergent insoluble $\mathrm{N}$ values of heat treated oilseeds indicated no indigestible complexes were formed. In conclusion, roasting or extrusion can be used to increase the undegradable $\mathrm{N}$ fraction of linseed and soybean to increase the dietary protein availability for digestion in ruminants, but was less effective for canola. The present heat treatments did not damage the protein or affect the $\mathrm{N}$ digestibility of the oilseeds.
\end{abstract}

Key words: extrusion, in vitro, $\mathrm{N}$ degradability, $\mathrm{N}$ digestibility, oilseed, roasting

Abbreviations: AA, amino acid; ADF, acid detergent fibre; ADIN, acid detergent insoluble nitrogen; CP, crude protein; EE, ether extract; FA, fatty acid; aNDF-NDF, neutral detergent fibre using amylase, ash inclusive; $\mathrm{N}$, nitrogen

\section{Introduction}

The protein requirements of high producing ruminants often cannot solely be met by microbial synthesis during rapid growth or lactation. Oilseeds provide an excellent source of protein and an energyrich supplement for ruminant diets. The extent that oilseeds are degraded in the rumen determines the supply and quality of protein, specifically the amino acid (AA) profile, available for absorption in the small intestine. In general, rolled or ground raw oilseeds are highly degradable by microbes in the rumen, reducing their protein feed value. Heat treating oilseeds can decrease $\mathrm{N}$ degradability in the rumen, increasing the amount of dietary protein available for post-ruminal absorption. Effective heat treatment creates cross-linkages between peptide chains as well as exposing hydrophobic regions of peptide-carbohydrate complexes, rendering the proteins less susceptible to $\mathrm{N}$ degradation (Deacon et al. 1988). Adequate heat treatment is necessary 
Vol. 20(2011): 298-304.

to denature the protein whereas overheating may lead to the formation of indigestible compounds via Maillard reactions (NRC 2001).

Heat treatment of oilseeds has been used to increase the proportion of rumen undegradable $\mathrm{N}$ with varying degrees of success. The undegradable $\mathrm{N}$ fraction of soybean was increased by extrusion (González et al. 2002), whereas extrusion decreased the undegradable $\mathrm{N}$ fraction of linseed (Mustafa et al. 2003) and canola (Ferlay et al. 1992). The oil content of oilseeds is one factor that can impede the rearrangement of protein bonds during the extrusion process (Ferlay et al. 1992). Roasting has been shown to increase the undegradable $\mathrm{N}$ fraction for canola (Dakowski et al. 1996), soybean (Faldet et al. 1992) and linseed (Petit et al. 2002).

Determination of $\mathrm{N}$ degradability and $\mathrm{N}$ digestibility of oilseeds using cannulated animal-based models is costly and labour intensive. Calsamiglia and Stern (1995) developed an enzyme-based in vitro method for assessing $\mathrm{N}$ digestibility using pepsin-pancreatin solutions; however, the samples must be pre-incubated in the rumen. Enzyme-based in vitro methods are cheaper to operate and negate the need for cannulated animals. The $\mathrm{N}$ degradability and $\mathrm{N}$ digestibility values of roasted soybeans using a two-stage enzyme-based in vitro method were comparable to in sacco and mobile-bag estimates (McNiven et al. 2002).

The objective of this trial was to compare the effectiveness of roasting or extrusion heat treatments to increase the $\mathrm{N}$ degradability and $\mathrm{N}$ digestibility of canola, linseed and soybean compared to raw oilseeds evaluated by an enzyme-based in vitro method.

\section{Materials and methods}

\section{Feedstuffs}

Batches of canola, linseed and soybean were purchased from local producers. Each batch was divided into three sub-batches for treatment: unprocessed, roasted or extruded. Canola and linseed were roasted at $121^{\circ} \mathrm{C}$ for $45 \mathrm{~s}$, while soybeans were roasted at $143{ }^{\circ} \mathrm{C}$ for $60 \mathrm{~s}$, on a Calormatic ${ }^{\circledR}$ fluidized bed roaster (Sweet Manufacturing, $\mathrm{OH}, \mathrm{USA}$ ). Canola and linseed were extruded at $72^{\circ} \mathrm{C}$ for $30 \mathrm{~s}$ and for soybean it was $130{ }^{\circ} \mathrm{C}$ for $30 \mathrm{~s}$, using a single screw Insta-Pro extruder (Triple F Inc. IA, USA). Selected temperatures were representative of commercial settings. Following treatment, each sub-batch was ground through a $2 \mathrm{~mm}$ screen using a Retch Ultra Centrifuge Mill (ZM100; Fisher Scientific Co., ON, Canada).

\section{Chemical analysis}

According to AOAC methods (2000), moisture (934.01), crude protein (CP; Kjeldahl N x 6.25, 984.13) and ether extract (EE, 920.39) were determined. Extraction of detergent fibre using filter bags followed the procedure of Ankom Technology (aNDF-NDF, neutral detergent fibre using amylase, ash inclusive method 6; ADF, acid detergent fibre, method 5) as referred by Ferreira and Mertens (2007). Values for ADF and aNDF-NDF were expressed as $\mathrm{g} \mathrm{kg}^{-1} \mathrm{DM}$. Residual contents of bags after ADF analysis were recovered and used for acid detergent insoluble $\mathrm{N}$ (ADIN) determination. The ADIN content was measured as N x 6.25 after analysis with a Leco CHN 2000 analyzer (Leco Corp. MI, USA) and expressed as $\mathrm{g} \mathrm{kg}^{-1} \mathrm{CP}$.

\section{In vitro procedure}

The in vitro process followed the procedure of McNiven et al. (2002). Six samples of each oilseed from the three processing treatments were weighed (about $1 \mathrm{~g}$ accurately) and sealed in Ankom bags (F57, pore size $50 \mu \mathrm{m}$; Ankom Technology, NY, USA). Briefly, the bags were incubated at $39^{\circ} \mathrm{C}$ for $4 \mathrm{~h}$ in protease solution (protease type xiv from $\mathrm{S}$. griseus in borate-phosphate buffer, P-5147, Sigma-Aldrich Ltd., Canada). After incubation, three random bags from each treatment were removed for determination of $\mathrm{N}$ degradability. Remaining samples to be 
Turner, T. D. and McNiven, M.A. In vitro degradability of heat treated oilseeds

used for determining $\mathrm{N}$ digestibility were incubated at $39{ }^{\circ} \mathrm{C}$ for $1 \mathrm{~h}$ in pepsin solution (P-7000 solution; $2 \mathrm{mg} / \mathrm{ml}$ in $0.1 \mathrm{~N} \mathrm{HCl}$, Sigma-Aldrich Ltd., Canada), rinsed and then incubated at $39^{\circ} \mathrm{C}$ for 24 $\mathrm{h}$ in pancreatin solution (P-7545, Sigma-Aldrich Ltd., Canada). Bags were rinsed thrice after their respective incubation end-points before $\mathrm{N}$ analysis (AOAC 2000). The $\mathrm{N}$ degradability was calculated as the difference between the $\mathrm{N}$ in the feed and the $\mathrm{N}$ remaining after the protease incubation, divided by the $\mathrm{N}$ in the feed. The $\mathrm{N}$ digestibility was calculated as the difference between the $\mathrm{N}$ in the feed and the $\mathrm{N}$ remaining after the pancreatin incubation, divided by the $\mathrm{N}$ in the feed. The $\mathrm{N}$ value from each sample was used as the experimental unit.

\section{Statistics}

The $\mathrm{N}$ degradability and $\mathrm{N}$ digestibility results were analysed using a two-way ANOVA testing for main and interaction effects between oilseed type and heat treatment using the GLM procedure of Statistical Analysis Software v9.1 (2002). The Bonferroni adjustment was used for making protected comparisons of the means $(p<0.05)$. Estimates of the interaction least square means are presented along with the standard error of the means (SE).

\section{Results}

\section{Chemical analysis of oilseeds}

The CP fractions of canola and linseed were not affected by heat treatment, whereas the CP fraction of soybean decreased by roughly $15 \%$ following heat treatment (Table 1). The EE fraction of canola was increased by the heat treatments, whereas the EE fractions of linseed and soybean were not affected. Heat treatment decreased the aNDF-NDF fraction of canola and linseed by roughly $50 \%$ and $40 \%$ respectively, whereas the aNDF-NDF fraction of soybean was decreased $16 \%$ by roasting and $30 \%$ by extrusion. The ADF fraction of canola was decreased by roughly $40 \%$ and the linseed ADF by roughly $15 \%$ by roasting or extrusion. The heat treatments affected soybean ADF differently with roasting and extrusion decreasing the ADF values roughly $31 \%$ and $46 \%$, respectively. Roasting or extrusion decreased the ADIN value for canola and linseed by roughly $33 \%$ (Table 1 ). The soybean ADIN values were decreased by roughly $63 \%$ and $93 \%$ after roasting or extrusion, respectively.

\section{Oilseed $\mathrm{N}$ degradability and $\mathrm{N}$ digest- ibility}

There was an interaction effect between the oilseed type and heat treatment for the $\mathrm{N}$ degradability and $(p<0.001) \mathrm{N}$ digestibility $(p<0.05)$.

Table 1. Chemical composition of raw, roasted or extruded samples of canola, linseed and soybean.

\begin{tabular}{|c|c|c|c|c|c|c|c|c|c|}
\hline & \multicolumn{3}{|c|}{ Canola } & \multicolumn{3}{|c|}{ Linseed } & \multicolumn{3}{|c|}{ Soybean } \\
\hline & Raw & Roasted & Extruded & Raw & Roasted & Extruded & Raw & Roasted & Extruded \\
\hline Dry Matter, $\mathrm{g} \mathrm{kg}^{-1}$ & 910 & 959 & 936 & 902 & 952 & 920 & 864 & 941 & 914 \\
\hline $\mathrm{CP}, \mathrm{g} \mathrm{kg}^{-1} \mathrm{DM}$ & 224 & 214 & 209 & 225 & 230 & 235 & 435 & 358 & 375 \\
\hline $\mathrm{EE}, \mathrm{g} \mathrm{kg}^{-1} \mathrm{DM}$ & 369 & 442 & 458 & 332 & 363 & 330 & 155 & 180 & 163 \\
\hline aNDF-NDF, $\mathrm{g} \mathrm{kg}^{-1} \mathrm{DM}$ & 194 & 110 & 116 & 127 & 107 & 109 & 97,9 & 67,3 & 52,4 \\
\hline ADF, $\mathrm{g} \mathrm{kg}^{-1} \mathrm{DM}$ & 276 & 145 & 122 & 256 & 157 & 153 & 135 & 112 & 91,9 \\
\hline ADIN, $\mathrm{g} \mathrm{kg}^{-1} \mathrm{CP}$ & 74,2 & 47,6 & 51,6 & 44,2 & 29,6 & 28,6 & 61,9 & 22,6 & 4,5 \\
\hline
\end{tabular}


Vol. 20(2011): 298-304.

Compared to raw samples, the $\mathrm{N}$ degradability of linseed and soybean was decreased after roasting or extrusion $(p<0.05)$ (Fig. 1). The $\mathrm{N}$ degradability of canola was higher after extrusion $(p<0.001)$. Raw soybean $\mathrm{N}$ degradability was higher than raw canola or linseed $(p<0.001)$. The $\mathrm{N}$ degradability of roasted canola or soybean was significantly higher than roasted linseed $(p<0.01)$. The $\mathrm{N}$ degradability of extruded canola was higher than that of extruded linseed or soybean $(p<0.001)$.
The $\mathrm{N}$ digestibility of the individual oilseeds did not differ between the raw and heat treated samples ( $p>0.05)$ (Fig. 2). Soybean had the highest $\mathrm{N}$ digestibility within each heat treatment $(p<0.05)$. The $\mathrm{N}$ digestibility of canola and linseed were similar for raw or roasted samples $(p>0.05)$. The $\mathrm{N}$ digestibility of extruded canola was higher than extruded linseed $(p<0.001)$.
Fig. 1. Least squares means for oilseed $\mathrm{N}$ degradability ( $\mathrm{SE}=$ 21.4), values as measured in vitro. Means with different letters (a-d) indicate significant difference $(p<0.05)$

Fig. 2. Least squares means for oilseed $\mathrm{N}$ digestibility $(\mathrm{SE}=9.3)$, values as measured in vitro. Means with different letters (ad) indicate significant difference $(p<0.05)$
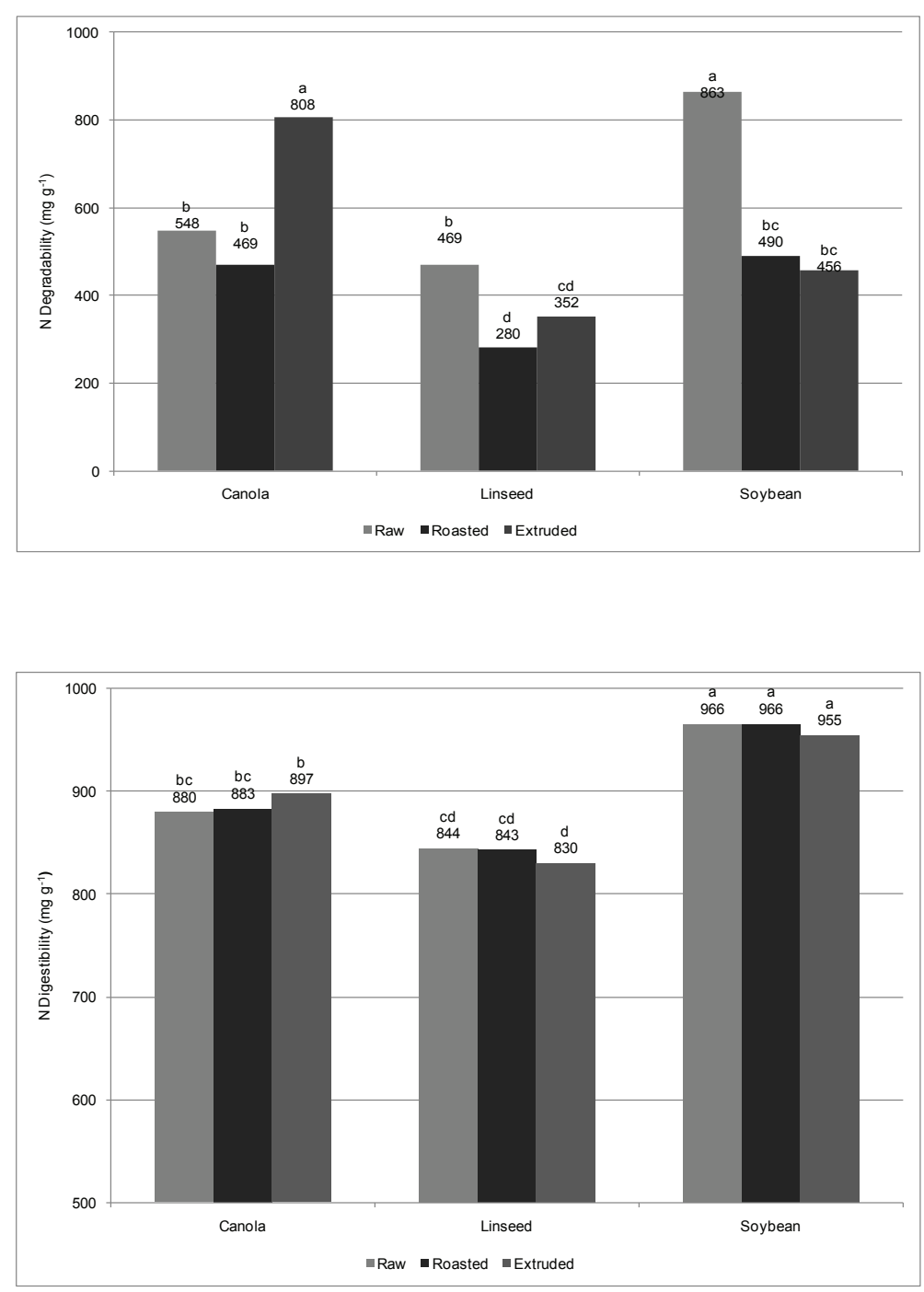
Turner, T. D. and McNiven, M.A. In vitro degradability of heat treated oilseeds

\section{Discussion}

\section{Chemical composition of oilseeds}

Moisture loss during heat treatment may account for the increased canola $\mathrm{EE}$ content. The reduction in soybean $\mathrm{CP}$ content following heat treatment probably was due to hull loss during heat treatment. Similarly, hull loss due to physical contact during roasting or shearing effect during extrusion could account for the reduction in aNDF-NDF of all oilseeds. Reductions in the aNDF-NDF fraction after heat treatment have been previously reported (Mustafa et al. 2003, Nasri et al. 2008). Moreover, the heat treatments reduced the oilseed ADIN fraction. Lowering the proportion of ADIN has been shown to increase the available $\mathrm{N}$ and releasing some AA (Nasri et al. 2008). The ADIN fraction of canola and linseed was reduced after heat treatment to levels similar to their respective raw samples. The ADIN fraction of soybean was reduced more by extrusion than by roasting, suggesting an added benefit during the shearing processing. Most importantly, the ADIN fraction of the oilseeds was not increased by roasting or extrusion, which would have indicated heat damage.

\section{Processing method effect on $\mathrm{N}$ degrada- bility}

The interaction effect indicated that the present heat treatments affected the oilseeds differently. Lower $\mathrm{N}$ degradability may be considered as synonymous with higher undegradable N, which would imply a higher feeding value of the protein for ruminants. The present low undegradable $\mathrm{N}$ content of extruded canola was in agreement with the findings of Deacon et al. (1988) who reported undegradable $\mathrm{N}$ values in the range of 15 to $18 \%$. Ferlay et al. (1992) reported that extrusion increased the undegradable $\mathrm{N}$ fraction for most oilseeds except canola, concluding that the high oil content of canola decreased the retention time and heat build-up in the extruder, limiting protein denaturation. Compared to raw linseed, the undegradable $\mathrm{N}$ fraction of linseed was increased by extrusion in the present study. In contrast, Mustafa et al. (2003) reported that extrusion decreased the in situ undegradable $\mathrm{N}$ fraction of linseed from 360 $\mathrm{mg} \mathrm{g}^{-1}$ to $220 \mathrm{mg} \mathrm{g}^{-1}$, concluding that the $385 \mathrm{~g} \mathrm{~kg}^{-1}$ DM oil content of the linseed hindered the thermal effects inside the extruder. Differences in extrusion conditions as well as differences between in situ and in vitro methods may account for the present contradictory findings.

In agreement with the present study, roasting has been shown to increase the undegradable $\mathrm{N}$ fraction of soybean (González et al. 2002, McNiven et al. 2002) and linseed (Petit et al. 2002); however canola was only slightly increased. Khattab and Arntfield (2009) reported that roasting increased the disassociation of high molecular weight proteins, producing more denatured hydrophobic residues. This causes a shift in the hydrophobicity to hydrophilicity balance, reducing the susceptibility to enzyme activity (Moure et al. 2006).

\section{Oilseed type effect on $\mathrm{N}$ degradability}

The undegradable $\mathrm{N}$ fraction of linseed and soybean increased about $40 \%$ after roasting, whereas canola increased about $15 \%$. The differences in effectiveness of the roasting process could be related to the AA profile of the oilseeds and the greater proportion of hydrophobic AA found in linseed and soybean (Chung et al. 2005). Oilseeds with a greater proportion of methionine or cystine, as in linseed or soybean, respond more extensively to heat treatment via increased disulfide linkages. Mahadevan et al. (1980) reported an increased proportion of undegradable $\mathrm{N}$ based on the number of disulfide-bonds within the protein structure of protein supplements and Lykos and Varga (1995) reported an increase in the undegradable $\mathrm{N}$ level of oilseeds via the formation of disulfide bonds induced by heat treatment.

Similar to Ferlay et al. (1992), extrusion in the present study was unsuitable for increasing the undegradable $\mathrm{N}$ fraction of canola compared to linseed or soybean. The effectiveness of extrusion on linseed compared to canola given the similar oil 
contents reiterates the influence of the AA composition and their susceptibility to heat denaturation for increasing the undegradable $\mathrm{N}$ fraction.

\section{Oilseed $\mathrm{N}$ digestibility}

A high $\mathrm{N}$ digestibility infers a high proportion of the crude protein is available for absorption by the animal. The $\mathrm{N}$ digestibility differences observed between extruded oilseeds may be due to shearing differences incurred during extrusion. The $\mathrm{N}$ digestibility of linseed was slightly lower than that of canola after roasting or extrusion. As stated by Ferlay et al. (1992), variations in the protein subfractions, namely albumins and globulins, vary greatly between oilseed types, thus influencing the effectiveness of the extrusion process. Variations in these sub-fractions following heat treatment, namely $\alpha$-helix and $\beta$-sheet composition, can be indicative of changes to $\mathrm{N}$ digestibility (Marcone et al. 1998).

\section{Conclusions}

Roasting or extrusion increased the undegradable $\mathrm{N}$ fractions of soybean and linseed but was less effective for canola. The $\mathrm{N}$ digestibilities of the heat treated oilseeds were similar to those of raw oilseeds, indicating no heat damage or reduction of protein availability. In conclusion, heat treatment of these oilseeds may potentially improve the supply of dietary $\mathrm{N}$ available for digestion in ruminants.

Acknowledgements. The authors would like to thank A. Mitchell at the Dept. Health Management, Atlantic Veterinary College, University of Prince Edward Island, PE, Canada for technical assistance with the chemical analysis.

\section{References}

AOAC 2000. Official Methods of Analysis of AOAC International. 17th edition. Association of Official Analytical Chemists. Gaithersburg, MD, USA. 1200. p.

Calsamiglia S. \& Stern M. D. 1995. A 3-step in vitro procedure for estimating intestinal digestion of protiens in ruminants. Journal of Animal Science 73: 1459-1465.

Chung M. W. Y., Lei B. \& Li-Chan E. C. Y. 2005. Isolation and structural characterization of the major protein fraction from NorMan flaxseed (Linum usitatissimum L.). Food Chemistry 90: 271-279.

Dakowski P., Weisbjerg M. R. \& Hvelplund T. 1996. The effect of temperature during processing of rape seed meal on amino acid degradation in the rumen and digestion in the intestine. Animal Feed Science and Technology 58: 213-226.

Deacon M. A., De Boer G. \& Kennelly J. J. 1988. Influence of jet-sploding $(R)$ and extrusion on ruminal and intestinal disappearance of canola and soybeans. Journal of Dairy Science 71: 745-753.

Faldet M. A., Son Y. S. \& Satter L. D. 1992. Chemical, in vitro, and in vivo evaluation of soybeans heat-treated by various processing methods. Journal of Dairy Science 75: 789-795.

Ferlay A., Legay F., Bauchart D., Poncet C. \& Doreau M. 1992. Effect of a supply of raw or extruded rapeseeds on digestion in dairy cows. Journal of Animal Science 70: 915-923.

Ferreira G.\& Mertens D. R. 2007. Measuring detergent fibre and insoluble protein in corn silage using crucibles or filter bags. Animal Feed Science and Technology 133: 335-340

González J., Andrés S., Rodríguez C. A. \& Alvir M. R. 2002. In situ evaluation of the protein value of soybean meal and processed full fat soybeans for ruminants. Animal Research 51: 455-464.

Khattab R. Y. \& Arntfield S. D. 2009. Functional properties of raw and processed canola meal. LWT - Food Science and Technology 42: 1119-1124.

Lykos T. \& Varga G. A. 1995. Effects of processing method on degradation characteristics of protein and carbohydrate sources in situ. Journal of Dairy Science 78: 1789-1801.

Mahadevan S., Erfle J. D. \& Sauer F. D. 1980. Degradation of soluble and insoluble proteins by bacteroides amylophilus protease and by rumen microorganisms. Journal of Animal Science 50: 723-728.

Marcone M. F., Kakuda Y. \& Yada R. Y. 1998. Salt-soluble seed globulins of dicotyledonous and monocotyledonous plants II. Structural characterization. Food Chemistry 63: 265-274.

McNiven M. A., Prestløkken E., Mydland L. T. \& Mitchell A. W. 2002. Laboratory procedure to determine protein digestibility of heat-treated feedstuffs for dairy cattle. Animal Feed Science and Technology 96: 1-13.

Moure A., Sineiro J., Domínguez H. \& Parajó J. C. 2006. Functionality of oilseed protein products: A review. Food Research International 39: 945-963.

Mustafa A. F., Gonthier C. \& Ouellet D. R. 2003. Effects of extrusion of flaxseed on ruminal and postruminal nutrient 


\section{AGRICULTURAL AND FOOD SCIENCE}

Turner, T. D. and McNiven, M.A. In vitro degradability of heat treated oilseeds

digestibilities. Archives of Animal Nutrition 57: 455 - 463.

Nasri M. H. F., France J., Danesh Mesgaran M. \& Kebreab E. 2008. Effect of heat processing on ruminal degradability and intestinal disappearance of nitrogen and amino acids in Iranian whole soybean. Livestock Science 113: 43-51.

NRC 2001. Nutrient Requirements of Dairy Cattle. 7th edition. National Academy Press. Washington, D.C., USA. p. 408.

Petit H. V., Tremblay G. F., Tremblay E.\& Nadeau P. 2002. Ruminal biohydrogenation of fatty acids, protein degradability, and dry matter digestibility of flaxseed treated with different sugar and heat combinations. Canadian Journal of Animal Science 82: 241-250.

SAS. 2002. SAS/STAT9 User's Guide, Version 9.1.0. SAS Institute Inc., Cary, NC, USA. 